\title{
IMPROVEMENT OF CLASSIFICATION OF NON-CURRENT TANGIBLE ASSETS IN BUDGET INSTITUTIONS OF UKRAINE
}

\author{
Oleksandr Chereshnevyi ${ }^{1}$ \\ ${ }^{1}$ Department of Audit and State Control, Vinnytsia National Agrarian University, Vinnytsia, Ukraine \\ sashachereshnevy@gmail.com \\ ORCID: http://orcid.org/0000-0002-8469-9968
}

A R T I C LE IN F O
Article history:
Received date 12.01 .2021
Accepted date 18.02 .2021
Published date 22.02.2021
Section:
Management
D O I

$10.21303 / 2313-8416.2021 .001666$

KE Y W ORDS

fixed assets

non-current tangible assets

special purpose assets

classification of non-current tangible

assets
ABSTRACT

The object of research: This article explores the necessary ways to improve the classification of non-current tangible assets on the example of non-current tangible assets for special purposes.

Solved problem: bringing the classification of non-current tangible assets to the accounting needs of the institution will improve the structure, quality of accounting information reflected in the accounting registers and allow the application of uniform methodological provisions of accounting to such tangible assets.

Investigated problem: structuring the classification features of non-current tangible assets of budgetary institutions of Ukraine, which listen to modern requirements for the accumulation of information and the needs of internal and external users for the adoption of administrative management.

The main scientific results: The proposed approaches to the classification of non-current tangible assets, namely the attribution of non-current tangible assets for special purposes to fixed assets, will bring the accounting information of budgetary institutions to the economic essence of these assets. This, in turn, will improve the quality of accounting information for management decisions, reduce the number of errors in the reflection of business transactions with these assets. The ability of the existing classification of non-current tangible assets to structure the tangible assets according to their properties and technical characteristics is proved. To confirm the opinion about the inconsistency of the modern classification of non-current tangible assets, a comparative description of the properties of fixed assets, other non-current tangible assets, and non-current tangible assets for special purposes is given.

The area of practical use of the research results: the practical results of this study are primarily aimed at application in the activities of budgetary institutions of Ukraine. But it is also expedient to apply the obtained scientific achievements at the enterprises and establishments of the public sector.

Innovative technological product: approaches to the classification of non-current tangible assets in budgetary institutions with the simultaneous possibility of implementing the results obtained in existing software products for automation of settlement processes and budget accounting in general.

Scope of the innovative technological product: the results presented in this study are relevant and recommended for use in all budgetary institutions. It will be especially useful for implementation by senior fund managers whose functions are related to defense or law enforcement measures.

(C) The Author(s) 2021. This is an open access article under the CC BY license http://creativecommons.org/licenses/by/4.0).

\section{Introduction}

\section{1. The object of research}

The aim of this article is to study the nature of other non-current tangible assets for special purposes in order to form own vision of the classification of non-current tangible assets, taking into account the needs of accounting for the accumulation and systematization of information.

Currently, the existing classification structure of non-current tangible assets does not fully meet the properties of these objects, which requires careful study both from the scientific basis and from the practical use and application of accounting information. 


\section{2. Description of the problem}

Inhomogeneity of classification of non-current tangible assets according to their properties leads to difficulties in applying the methodological principles of accounting in practice. At present, non-current tangible assets for special purposes are part of other non-current tangible assets, although their qualitative and operational characteristics have a greater identity with fixed assets. The existing classification of non-current tangible assets leads to many exceptions in the national methodological provisions and principles of accounting for the reflection of business transactions, changes in the quality of these assets. In turn, the existence of exceptions in the general rules is the cause of several errors in accounting and complicates and increases the burden on accounting staff.

At present, the research of domestic scientists are mainly focused on the study of the economic essence of non-current tangible assets as part of fixed assets [1,2] and the solution of problematic issues in the implementation of their accounting. But the solution to any problem related to the accounting of non-current tangible assets must begin not only with theoretical analysis but also with the improvement of the existing classification.

\section{3. Suggested solution to the problem}

It is proposed to solve the identified problems in the classification of non-current tangible assets by improving the existing classification of these assets, namely the removal of non-current tangible assets for special purposes from other non-current tangible assets and adding them to fixed assets. The introduction of these changes, in turn, will lead to the need to adjust domestic regulations and standards governing the methodological issues of accounting for non-current tangible assets.

The aim of research includes further study and substantiation of the need to improve the classification of non-current tangible assets by comparing the properties of other non-current tangible assets, fixed assets, and non-current tangible assets for special purposes.

\section{Materials and methods}

Accounting in budgetary institutions provides a reflection of all operations related to the implementation of the budget expenditures, estimates of special funds and summarization of accounting and reporting necessary for the operational management, analysis, control over the targeted use of funds on the basis of estimates, the detection of unplanned and illegal costs. For this purpose, there are kept the records of:

- loans (appropriations) and expenditures of budgetary funds;

- receipt and spending of special funds;

- preservation and efficiency of the use of cash, tangible assets, equipment, food, medicines and other valuables;

- settlements with debtors and creditors, including payroll [1].

The major form of asset in the statement of financial position of most industries is tangible non-current assets. These assets are referred to as property, plant and equipment under International Accounting Standards (IAS) number 16, and are used for the production or supply of goods and services, for rental to others, or for administration purposes. Property, plant and equipment are expected to be used for more than one accounting period, and are capital intensive in nature. In many cases, they account for as much as eighty per cent or more of the total asset value of manufacturing companies [2].

Non-current tangible assets are a significant part of the assets in the budgetary institution, so the issues of improving its accounting support remain relevant today. The definition of non-current tangible assets is not common enough in the scientific literature or legislation, despite its importance and significance for the budgetary institution. Most of them are considered in terms of fixed assets or other non-current tangible assets, but still, there is some research in this area. Non-current tangible assets are proposed to be a set of commissioned tangible assets that belong to the institution, ensure its functioning in the process, and are depreciated over their useful usage (exploitation), which lasts more than one year [3].

In general, it is necessary to agree with the author's opinion on the interpretation of the term non-current tangible assets, but the question of assigning to non-current tangible assets only com- 
missioned assets remains quite debatable. Opinions on the necessity of their commissioning are ambiguous, in our opinion, to carry out full-fledged scientific research, it is necessary to expand the scope of research to those assets that at the time of reporting by the budgetary institution are not commissioned and used by the institution.

One of the broadest interpretations of the term non-current tangible assets proves that a characteristic feature of these assets is that they participate in the process of economic activity for a long time, many times, maintaining this natural form, which gradually loses, as the physical and moral solution. They include items that are consumed during a period exceeding twelve months from the balance sheet date, or the operating cycle if it is more than a year, and the value of each inventory unit exceeds the standard established and fixed in the order of the accounting policy of the person project management [4].

The process of classification of assets is the basis for the rational organization and formation of basic methodological rules of accounting. In essence, the classification performs a single function, which is to divide the objects of research on various grounds. Depending on the number of features, different approaches to classification are formed, thereby increasing the areas of the research. Scientifically based classification in practice is used to organize analytical and synthetic accounting of the presence and movement of objects, when calculating depreciation and determining the amount of depreciation, as well as when inventorying fixed assets [5].

Non-current tangible assets can be divided into two main components: fixed assets and other non-current tangible assets. The structure of other non-current tangible assets currently includes non-current tangible assets for special purposes, which in our opinion is imperfect and erroneous, because in their properties they are more identical to fixed assets.

Many domestic and foreign scientists deal with problematic issues related to the accounting and definition of fixed assets. Asset represents a resource controlled by entity as a result of some passed events from which it's expected to generate future economic benefits for the entity. The purpose of using it is the sustainable use, usually for more than one year [6]. Tangible assets are those assets that are used in the production process, int the marketing process or in the provision of services with a long term use, participating in several production cycles and whose value is transmitted gradually as depreciation expenses each financial year [7].

The tangible assets are material and value investments with the period of usage exceeding the length of a financial year. As these assets do not run to waste after their first usage, the depreciation process is used to consign that part of the value which is transmitted on, to the goods, workings and services [8].

Under international accounting regulations tangible non-current assets can be divided into two main groups: investment property and non-current tangible operating assets being usually called property, plant and equipment [9].

The rules for classifying fixed assets are primarily based on the functions they perform in an undertaking. Pursuant to the Regulation of the Council of Ministers of 10 December 2010, fixed assets include:

- immovable property (land, buildings, civil engineering structures);

- machines, technical equipment and tools;

- means of transport for persons or goods;

- livestock [10].

From the legislative point of view of Ukraine, fixed assets are tangible assets that are held for use in activities or in the supply of goods, works and services to achieve the goal and/ or meet the needs of a public sector entity or lease to others and are used, expected to be more than one year [11].

In regulations, fixed assets and other non-current tangible assets are combined into fixed assets, because they are similar in their properties and service life, a significant difference is in their value. After all, by the Guidelines, other non-current tangible assets should include items of production value worth up to 6,000 UAH per unit (set) without value-added $\operatorname{tax}[12]$. 
Non-current tangible assets for special purposes include assets used for defense and law enforcement purposes. These assets include military products, military equipment, aircraft, helicopters, their power plants, equipment for them, ships, boats, vessels, ship artillery shields and other vessels, weapons, naval equipment, military equipment, special purpose vehicles, etc. [13].

Confirmation of the opinion on the need to include non-current tangible assets for special purposes in fixed assets can be found by comparing the properties of these assets listed in Table 1.

Table 1

Comparison of properties of non-current tangible assets

\begin{tabular}{|c|c|c|c|}
\hline Properties & $\begin{array}{l}\text { Fixed } \\
\text { assets }\end{array}$ & $\begin{array}{l}\text { Other non-current } \\
\text { tangible assets }\end{array}$ & $\begin{array}{c}\text { Non-current tangible } \\
\text { assets for other purposes }\end{array}$ \\
\hline Comparison of properties of non-current tangible assets & + & - & + \\
\hline Depreciation of $50 \%$ upon introduction, $50 \%$ upon liquidation & - & + & - \\
\hline Assignment of the inventory number & + & + & + \\
\hline Assignment of a nomenclature number & - & + & + \\
\hline Limiting the value of the asset to $6,000 \mathrm{UAH}$. (excluding VAT) & - & + & - \\
\hline Possibility of revaluation & + & - & + \\
\hline
\end{tabular}

After examining and analyzing the nature of non-current tangible assets, it is possible to that it is necessary to change the classification structure of these assets. Analyzing the data presented in (Table 1) it is possible to conclude that non-current tangible assets for special-purposes are identical in properties to fixed assets.

Proof of this opinion can also be found by comparing assets that are part of fixed assets and non-current tangible assets for special purposes. For example, fixed assets and non-current tangible assets of special purpose include vehicles used for the transportation of citizens or cargo, the only difference is in the scope, as some are used in civilian budget institutions, others in military or law enforcement agencies.

The technical characteristics and operating conditions of these vehicles are almost the same and their separation into different classes of non-current tangible assets is impractical.

Also, the confirmation of the presence of non-current tangible assets for special purposes out of place in the structure of non-current tangible assets can be found by studying in detail the guidelines for an accounting of the public sector [12]. According to these rules, non-current tangible assets for special purposes are not subject to depreciation rules as for other non-current tangible assets, in 50 percent upon commissioning and 50 percent upon depreciation of this asset, and other features are mostly given in (Table 1).

Having identified this issue and explored the essence of non-current tangible assets, it is proposed to change the structure of the components of tangible assets of fixed assets and other non-current tangible assets (Fig. 1).

The proposals set out in (Fig. 1) take into account all the features of non-current tangible assets for accounting purposes. The proposed classification structure reflects the practice of using accounting accounts in budgetary institutions and takes into account the work of scientists in this field. The combination of these components in the classification of non-current tangible assets will help to form the accounting system of these assets in accordance with the requirements of international accounting standards.

The use of the cost method to classify an asset as property, plant and equipment or other non-current tangible assets is an outdated and unjustified economic method, as it forces the heads of budgetary institutions to adjust expenditure plans and break the value of these assets under the law.

For example, there is a practice of combining several other non-current tangible assets into a single set to include them in capital expenditures, then fixed assets, or, conversely, bud- 
getary institutions disassemble computer equipment into different components to include them in current expenditures, subsequently to other non-current tangible assets. The existence of such a legal framework for the acquisition of non-current tangible assets not only complicates the accounting process in the institution, but also forces the heads of budgetary institutions to adapt to existing expenditure targets, which significantly reduces the efficiency of management decisions and receipt of these assets in the budgetary institution.

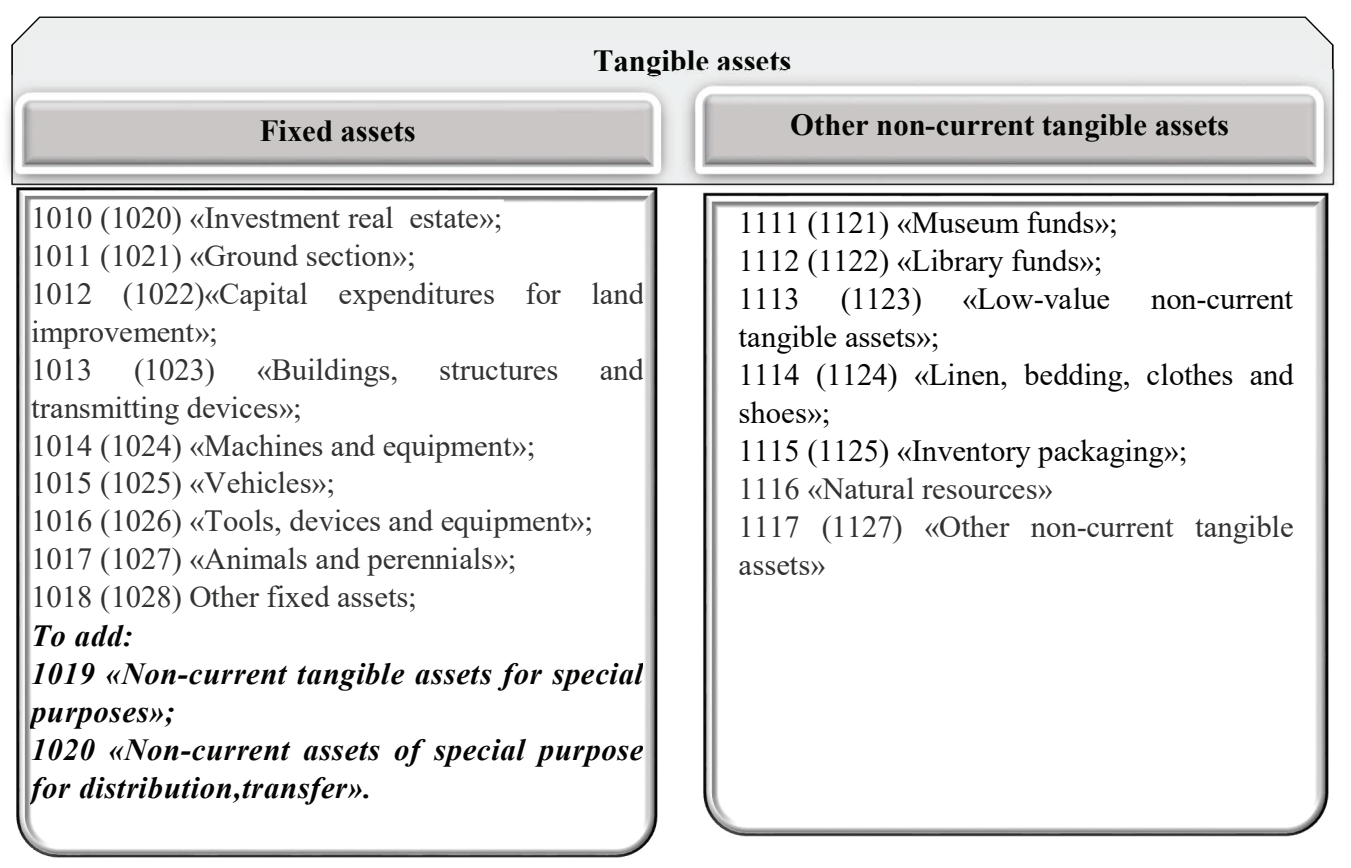

Fig. 1. Improving the classification structure of non-current tangible assets in budgetary institutions of Ukraine

Modern experience of foreign and domestic regulation of determining the affiliation of an asset to fixed assets or other non-current tangible assets does not provide for determination by cost criterion. First of all, employees of budgetary institutions need to pay attention to the economic essence of this asset, namely the possibility of its reuse in the production or operation of the budgetary institution. Assets used in a budgetary institution for multiple production purposes should be classified as property, plant and equipment, while assets that serve as ancillary equipment to property, plant and equipment and whose useful life is more than one year should be attributed to other non-current tangible assets.

\section{Results and discussion}

The results of this research are to prove the need to improve the classification structure of non-current tangible assets in budgetary institutions by classifying non-current tangible assets for special purposes as fixed assets. Existing research on the classification of non-current tangible assets has not paid enough attention to detailing the classification features $[3,5,9,10]$.

The implementation of the obtained results allows not only to bring the structure of non-current tangible assets to the characteristic properties but also to create a single unified accounting provision for this group of assets. In the future, this will help simplify the rules of accounting in budgetary institutions and as a consequence reduce errors in business transactions and enter them in the accounting registers. Also, the introduction of the proposed classification will provide quality accounting information on the movement of non-current tangible assets for management purposes.

Research on this topic is complicated by insufficient scientific work by domestic and foreign experts on the nature and classification of non-current tangible assets. At present, the term non-current tangible assets are not defined by law, and a small number of scientists study the problems of accounting for budgetary institutions $[6,7]$. 
In the classical political-economic definition of fixed assets there are no restrictions the amount of their value in monetary terms. It is only important that they participate in the production process repeatedly and transfer their value to the manufactured product in parts [14].

Limitations in these studies are manifested in the lack of reliable statistical information on the structure of non-current tangible assets and their qualitative components at the state level, so to study their nature, classification and quality characteristics based on indicators at the budgetary institution.

The further development of the results of this study is the transition from the classification of non-current tangible assets to the definition of the value criterion in the presentation of these assets in the accounting of budgetary institutions. The application of the cost criterion significantly complicates the work of employees of the accounting department of budgetary institutions and does not have a sufficient methodological justification.

\section{Conclusions}

Summarizing all the above, it can be argued that the accounting of non-current tangible assets in budgetary institutions of Ukraine is currently in the process of transformation to international standards and regulations. But for the successful implementation of these measures, it is necessary to carry out an internal transformation of national regulations and accounting rules, one of such areas of transformation is the accounting of non-current tangible assets.

There is an extensive system of research in the field of accounting for non-current tangible assets, but a significant disadvantage in this area is the small percentage of their practical implementation and application in the activities of budgetary institutions. As a result, many recommendations of scientists remain without implementation, practical testing and do not find their further development. The combination of these factors leads to a decrease in the interest of scientists in conducting modern research in the field of accounting for non-current tangible assets in budgetary institutions.

The proposed structure of classification of non-current tangible assets and the addition of non-current tangible assets for special purposes to fixed assets will address a number of the following issues:

- will allow unifying uniform norms and rules of accounting for homogeneous non-current tangible assets;

- improve the quality of accounting information for management purposes;

- will help reduce the number of technical and methodological errors associated with the movement of non-current tangible assets;

- accelerate the efficiency of management decisions by the head of the budget institution;

- will create preconditions and a basis for further improvement of accounting of non-current tangible assets of budgetary institutions of Ukraine.

\section{References}

[1] Koval, N. (2020). Budget system and accounting in budgetary institutions. Three Seas Economic Journal, 1 (1), 7-13. doi: http://doi.org/10.30525/2661-5150/2020-1-2

[2] Chukwu, G. J., Egbuhuzor, C. A. (2017). Tangible Assets and Corporate Performance: Evidence from the Manufacturing Industry in Nigeria. Research Journal of Financial Sustainability Reporting, 2 (1), 271-277. Available at: https://www.researchgate.net/publication/336241796 Last accessed: 20.01.21

[3] Hurieva, I. M. (2014). Economic and Accounting Substance of the Non-Current Tangible Assets. Biznes Inform, 10, $312-317$. Available at: http://nbuv.gov.ua/UJRN/binf_2014_10_52 Last accessed: 20.12.2020

[4] Stepanenko, O. (2020). Non-current tangible assets in the enterprise's depreciation policy. Scientific Opinion: Economics and Management, 1 (67), 186-192. doi: http://doi.org/10.32836/2521-666x/2020-67-30

[5] Yaremenko, L. M. (2015) Theoretical approaches to the nature and classification of fixed assets. Ekonomichnyi visnyk universytetu, 27 (1), 144-148. Available at: http://nbuv.gov.ua/UJRN/ecvu_2015_27\%281\%29_24 Last accessed: 20.12.2020

[6] Dreghiciu, A. E. (2015). The Aspects of Revaluation of Tangible Assets. Ovidius University Annals, Economic Sciences Series, 15 (2), 428-433. Available at: https://ideas.repec.org/a/ovi/oviste/vxvy2015i2p428-433.html

[7] Loredana, E. M. (2016). Dynamic and Structural Analysis of Tangible Assets. Annals-Economy Series, 1, 223-228. Available at: https://www.utgjiu.ro/revista/ec/pdf/2016-Special\%20ECOTREND\%20Vol\%201/39_ECOBICI\%20MIHAELA\%20 LOREDANA.pdf Last accessed: 10.01.2021 
[8] Radu, D., Marius, D. (2011). Issues related to the accounting treatment of the tangible and intangible assets depreciation. Annals of the University of Oradea, Economic Science Series, 20 (2), 498-502.

[9] Frendzel, M. (2011). The use of fair value in measurement of non-current tangible assets by listed companies in Poland. Folia oeconomica, 257, 187-202. Available at: https:/dspace.uni.lodz.pl/bitstream/handle/11089/740/187-202.pdf Last accessed: 12.01.2021

[10] Glebocka, M., Mackowiak, E. (2020). Valuation and classification of fixed assets in selected local government. Economic and Social Development. Rabat, 47-61. Available at: https://bib.irb.hr/datoteka/1057353.Book_of_Proceedings_esdRabat2020_ Online.pdf\#page=56 Last accessed: 20.01 .2021

[11] Pro zatverdzhennia natsionalnykh polozhen (standartiv) bukhhalterskoho obliku v derzhavnomu sektori 121 "Osnovni zasoby" (2010). Nakaz Ministerstva finansiv Ukrainy No. 1202. 12.10.2010. Available at: https://zakon.rada.gov.ua/laws/show/ z1017-10\#n18 Last accessed: 15.01.2021

[12] Pro zatverdzhennia Metodychnykh rekomendatsii z bukhhalterskoho obliku dlia subiektiv derzhavnoho sektoru (2015). Nakaz Ministerstva finansiv Ukrainy No. 11. 23.01.2015. Available at: https://zakon.rada.gov.ua/rada/show/v0011201-15 Last accessed: 15.01 .2021

[13] Pro zatverdzhennia Instruktsii shchodo zastosuvannia ekonomichnoi klasyfikatsii vydatkiv biudzhetu ta Instruktsii shchodo zastosuvannia klasyfikatsii kredytuvannia biudzhetu (2012). Nakaz Ministerstva finansiv Ukrainy No. 333. 12.03.2012. Available at: https://zakon.rada.gov.ua/laws/show/z0456-12 Last accessed: 15.01.2021

[14] Dombrovska, N. R. (2012) The economic essence fixed assets and their classification. Ekonomichni nauky. Seriia: Oblik i finansy, 9 (1), 340-349. Available at: http://nbuv.gov.ua/UJRN/ecnof_2012_9(1)__51 Last accessed: 16.01.2021 